\title{
ANALISIS ONOMATOPE PADA DONGENG BAHASA JEPANG
}

\author{
I.A.W. Purwani ${ }^{1}$, N.N. Suartini ${ }^{2}$, K.E.K. Adnyani ${ }^{3}$ \\ ${ }^{123}$ Jurusan Bahasa Asing, Universitas Pendidikan Ganesha, Singaraja \\ e-mail: ayu.widya.purwani@undiksha.ac.id, nnsuartini@undiksha.ac.id, \\ krishna.adnyani@undiksha.ac.id
}

\begin{abstract}
Abstrak
Penelitian ini bertujuan untuk mendeskripsikan jenis onomatope yang terdapat dalam dongeng bahasa Jepang dan mendeskripsikannya. Subjek penelitian ini adalah 3 dongeng bahasa Jepang karya Hirata Shogo, yaitu Omusubi Kororin, Tsuru no On'gaeshi, dan Issunboushi. Penelitian ini merupakan penelitian deskriptif kualitatif dengan pengolahan data menggunakan kartu data. Teori yang digunakan adalah klasifikasi onomatope menurut Kindaichi dan Asano (1978). Hasil dari penelitian ini adalah ditemukan 35 data onomatope, tetapi tidak ditemukan gijougo dalam subjek data. Hal ini karena pada dongeng lebih banyak mendeskripsikan tindakan dan bunyi untuk menggambarkan tingkah laku tokoh dan kondisi sekitar. Kemudian ditemukan bahwa makna onomatope pada dongeng sangat beragam dan terdapat onomatope yang memiliki penulisan yang berbeda, tetapi memiliki makna yang mirip atau sebaliknya.
\end{abstract}

Kata kunci : bahasa Jepang, dongeng, makna, onomatope

\section{要旨}

本研究の目的は日本昔話にオノマトペの種類と意味を説明することである。調査対象は平田昭吾の日 本昔話、つまり「お結びころりん」、「鶴の恩返し」、「いっすんぼうし」である。データカードを 作成した後、オノマトペの分類の金田一と浅野（1978）理論を用い定性的記述法により分析した。収 集したデータは 35 データである。しかし擬情語データが見つけない。日本昔話に、音、声、行動を より詳しく説明するから。オノマトペの役割は表現を強調することが出来る。オノマトペの使用は柔 軟であることが分かる。日本のオノマトペの意味が多く。書き方は同じですが、意味が異なって、書 き方は違いですが、意味が同じである。

キーワード：日本語、昔話、意味、オノマトペ

\section{Pendahuluan}

Onomatope merupakan suatu gaya bahasa yang meniru suara makhluk hidup dan bunyi yang ada di lingkungan sekitar atau menggambarkan suatu keadaan tertentu. Onomatope mengganti atau mengubah suara-suara yang berasal dari alam menjadi suatu rangkaian kata yang dapat ditiru oleh manusia (Assaneo, 2011). Tidak hanya tiruan dari alam, tetapi onomatope juga merupakan tiruan dari suara, bunyi, atau keadaan yang dialami oleh manusia atau hewan. Onomatope dapat ditemukan dalam setiap bahasa salah satunya bahasa Indonesia. Contoh onomatope dalam bahasa Indonesia seperti meong-meong yang menggambarkan suara kucing, tik tik yang menggambarkan bunyi rintik hujan, terbahakbahak yang menggambarkan suara orang tertawa dengan kencang, dan masih banyak lagi.

Onomatope dalam bahasa Indonesia hanya memiliki satu istilah untuk menyebut katakata tersebut, sedangkan dalam bahasa Jepang memiliki banyak istilah dan dikelompokkan berdasarkan jenisnya. Onomatope bahasa Jepang dibagi menjadi 5 klasifikasi, yaitu gion'go (擬音語), giseigo (擬声語), gitaigo (擬態語), giyougo (擬容語), dan gijougo (擬情語). Gion'go (擬音語) menggambarkan tiruan bunyi yang berasal dari alam atau benda mati, giseigo (擬 声語) menggambarkan tiruan bunyi yang berasal dari makhluk hidup, gitaigo (擬態語) menggambarkan keadaan dari benda mati atau situasi tertentu, giyougo (擬容語) menggambarkan suatu keadaan dari makhluk hidup, dan gijougo (擬情語) menggambarkan suasana hati manusia (Kindaichi dan Asano, 1978 dalam Hinata dan Hibiya, 1989).

Onomatope sering digunakan oleh masyarakat Jepang dalam percakapan sehari-hari. Selain itu onomatope juga sering dijumpai pada anime, komik, novel atau bahasa tulis lainnya. Salah satu bacaan yang banyak menggunakan onomatope di dalamnya adalah 
dongeng anak-anak atau cerita anak-anak. Buku cerita atau dongeng adalah sebuah cerita yang tidak hanya terdapat tulisan, tetapi disisipkan beberapa ilustrasi dari cerita tersebut. Tema cerita yang banyak diambil adalah tentang kehidupan hewan atau interaksi antara hewan dan manusia. Penulis cerita harus mampu membuat cerita menjadi menarik dan lebih hidup sehingga dapat membangkitkan imajinasi anak-anak. Oleh karena itu, penulis cerita memerlukan kata-kata yang dapat meniru suara-suara terkait seperti suara benda, tindakan, atau makhluk hidup sehingga penulis cerita dongeng menggunakan onomatope dalam cerita mereka. Onomatope dalam dongeng sangat bagus untuk membuat anak-anak tertarik dan lebih memahami cerita tersebut karena mudah diingat (Kinasih, 2018). Hal ini karena onomatope permainan bunyi yang menarik dan mendekati bahasa anak seperti wanchan (ワ) ンちゃん) untuk menyebut anjing dan nyanchan (ニャンちゃん) untuk menyebut kucing.

Berdasarkan latar belakang tersebut, onomatope bahasa Jepang sangat menarik untuk diteliti karena memiliki ragam yang sangat banyak dan gaya bahasa yang unik dalam bahasa Jepang. Banyaknya ragam onomatope dalam bahasa Jepang membuat sebagian orang kesulitan untuk mengingatnya. Jika kesulitan dalam mengingat onomatope khususnya makna dari onomatope tersebut, tentu tidak akan bisa mengaplikasikannya di dalam kalimat. Penelitian ini membantu agar pembaca dapat mengetahui onomatope dan maknanya, jenis onomatope tersebut, dan penggunaannya secara kontekstual melalui dongeng bahasa Jepang. Hal ini karena dalam dongeng menggunakan bahasa yang sederhana sehingga lebih mudah dipahami dan terdapat alur cerita yang memudahkan pembaca untuk memahami makna onomatope tersebut secara lebih nyata. Analisis yang dilakukan adalah mencari onomatope-onomatope yang terdapat di dalam cerita, mengklasifikasikan sesuai jenis, dan menganalisis arti dari onomatope tersebut.

Penelitian onomatope dalam dongeng bahasa Jepang ini menggunakan dongeng karya Hirata Shogo dengan 3 judul dongeng, yaitu Omusubi Kororin, Tsuru no On'gaeshi, dan Issunboushi. Buku dongeng karya Hirata Shogo telah dikenal masyarakat sejak tahun 1993 dan merupakan buku dongeng yang di dalamnya disisipkan gambar animasi sehingga sangat menarik untuk dibaca. Dipilih 3 judul dongeng adalah karena pada 3 judul dongeng tersebut terdapat variasi makna dan data-data yang mendukung dalam menganalisis data.

Pada penelitian sebelumnya sudah banyak yang meneliti mengenai onomatope dalam berbagai subjek data, seperti komik, lagu, dan novel. Salah satunya meneliti onomatope bahasa Jepang yang terdapat pada novel Ginga Tetsudou no Yoru karya Muyazawa Kenji (1896-1833). Penelitian ini mengenai onomatope bahasa Jepang yang diterjemahkan ke dalam bahasa Inggris. Ada beberapa onomatope bahasa Jepang yang tidak dapat diterjemahkan ke dalam bahasa Inggris karena tidak terdapat padanannya. Namun, pada penelitian kali ini mencoba untuk meneliti makna dan jenis onomatope yang terdapat dalam dongeng bahasa Jepang.Penelitian ini merupakan penelitian deskriptif kualitatif dengan rumusan masalah sebagai berikut.

1. Apa saja jenis onomatope yang terdapat di dalam dongeng bahasa Jepang?

2. Apa makna onomatope yang terdapat pada kalimat di dalam dongeng bahasa Jepang?

\section{Semantik}

Semantik adalah salah satu cabang ilmu linguistik yang mengkaji tentang arti atau makna pada suatu bahasa. Semantik dapat dibedakan menjadi dua jenis, yaitu semantik gramatikal dan semantik leksikal (Verhaar, 2008 : 385) dan dalam bahasa Jepang ilmu yang mempelajari tentang suatu makna bahasa disebut dengan 'imiron' (意味論) yang berarti "ilmu makna". Makna leksikal disebut juga sebagai makna kamus yaitu makna yang sebenarnya dan bersifat tidak mengikat. Sedangkan makna gramatikal adalah makna yang mengacu pada satuan gramatika tertentu dan bersifat mengikat antara morfem satu dan lainnya, kata dengan kata, maupun kata dan morfem (Tjandra, 2014: 2). 


\section{Dongeng}

Dongeng adalah sebuah karya sastra yang di dalamnya bercerita tentang hal-hal yang luar biasa di luar nalar yang penuh khayalan (fiksi) dan tidak benar-benar terjadi (Dudung, 2015 dalam Habsari, 2017: 21-29). Cerita di dalam dongeng biasanya berisi sesuatu yang menghibur, tetapi di dalamnya tetap terdapat ajaran moral yang dapat dicontoh oleh pembacanya.

\section{Onomatope}

Onomatope adalah penggunaan konsonan dan vokal dari suara atau bunyi yang didengar dan ditiru ke dalam kata-kata sehingga pendengar dan pembaca berimajinasi. Hal ini membuat tulisan dan ucapan menjadi lebih bersemangat dan efektif. Contohnya dalam bahasa Inggris seperti "snap" dan "scratch" (Hadi, 2013). Onomatope merupakan salah satu bagian dari adverbia. Adverbia memiliki fungsi untuk menerangkan kata berdasarkan jenisnya seperti verba, nomina, adjektiva, dan jenis kata lainnya. Selain itu terdapat adverbia untuk menerangkan bunyi yang ada disekitar kita atau menerangkan suatu keadaan atau kondisi tertentu dan hal inilah yang disebut dengan onomatope (Mulya, 2013: 1). Dalam bahasa Jepang adverbia dikenal dengan istilah fukushi. Fukushi adalah kelas kata yang tidak mengalami perubahan bentuk dan dapat menjadi adverbia untuk yougen meskipun tidak mendapat bantuan dari kata-kata lainnya (Jidou Gengo Kenkyuukai, 1987: 92 dalam Sudjianto dan Ahmad Dahidi, 2012: 165).

Dalam bahasa Jepang ada beberapa onomatope yang memiliki banyak istilah, contohnya seperti onomatope yang menggambarkan keadaan atau kondisi berjalan sebagai berikut.

- Chokochoko aruku (ちょこちょこ歩く) yang artinya berjalan berayun.

- Tekuteku aruku (てくてく歩く) yang artinya berjalan dengan lesu.

- Tokotoko aruku (とことこ歩く) yang artinya berjalan cepat.

- Doshidoshi aruku(どしどし歩く) yang artinya berjalan dengan lambat.

- Tobotobo aruku (とぼとぼ歩く) yang artinya berjalan dengan langkah yang berat.

- Burabura aruku (ぶらぶら歩く) yang artinya jalan-jalan tanpa tujuan yang jelas.

- Yotayota aruku (よたよた歩く) yang artinya berjalan dengan terhuyung-huyung.

- Yochiyochi aruku (よちよち歩く) yang artinya berjalan tertatih seperti bayi.

(Hirose, 1981: 33 dalam Sato, 2017)

Klasifikasi Onomatope

Kindaichi dan Asano (1978) dalam Hinata dan Hibiya (1989: 1) menjelaskan pembagian atau klasifikasi onomatope secara lebih rinci sebagai berikut.

a. Giseigo (擬声語) adalah tiruan dari suara makhluk hidup.

こんこんが出るから、温かくして早く寝なさい。

Konkon ga deru kara, atatakaku shite hayaku nenasai.

"Karena batuk, hangatkanlah dirimu dan tidurlah lebih awal."

(Onomatope dalam Bahasa Jepang, 44)

b. Gion'go (擬音語) adalah tiruan dari suara benda mati atau lingkungan.

この辺は、夕方になるとぷうっとラッパをふきながらお豆腐やさんが回ってくるの よ。

Kono hen wa, yuugata ni naru to puutto rappa o fukinagara otoufuya-san ga mawatte kuru no yo.

"Setiap petang, penjual tahu datang kemari dan meniup terompetnya."

(Onomatope dalam Bahasa Jepang, 53)

Gitaigo (擬態語) secara umum diartikan sebagai sebuah kata yang mewakili sesuatu yang tidak menghasilkan suara atau bunyi. Gitaigo (擬態語) diklasifikasikan menjadi tiga bagian, yaitu gitaigo (擬態語), giyougo, dan gijougo. Gitaigo (擬態語) merupakan tiruan bunyi yang mewakili keadaan dari benda mati, giyougo merupakan tiruan bunyi yang menunjukkan 
kondisi makhluk hidup, dan gijougo merupakan sesuatu yang mewakili perasaan manusia (Hinata dan Hibiya, 1989: 1).

a. Gitaigo (擬態語) adalah menggambarkan keadaan benda mati atau situasi tertentu. このしつ、のりがききすぎてごわごわになっちゃったわ。

Kono shitsu, nori ga kikisugite gowagowa ni nacchatta wa.

"Kertas ini terlalu banyak perekat sehingga kaku seperti karton."

(Onomatope dalam Bahasa Jepang, 87)

b. Giyougo (擬容語) adalah menggambarkan keadaan atau tingkah laku makhluk hidup. このキムチ、おいしいけど辛いわね、舌にぴりぴりくるわ。

Kono kimuchi, oishii kedo karai wa ne. shita ni piripiri kuru wa.

"Kimchi ini rasanya enak, tetapi terlalu pedas. Lidah saya seperti terbakar rasanya."

(Onomatope dalam Bahasa Jepang, 17)

c. Gijougo (擬情語) adalah menggambarkan perasaan hati makhluk hidup.

この靴下、ずるずるずり落ちて困るんだ。

Kono kustushita, zuruzuru zuriochite komarun da.

"Saya tidak suka kaos kaki ini karena berulang kali melorot."

(Onomatope dalam Bahasa Jepang, 21)

\section{Metode}

Metode pengumpulan data yang digunakan adalah studi kepustakaan dengan mengumpulkan data berupa dongeng bahasa Jepang. Untuk menganalisis data yang telah didapat, penulis menggunakan buku-buku dan referensi terkait untuk menjadi acuan dalam menganalisis data pada sumber. Teknik yang digunakan adalah teknik catat, yaitu mencatat data-data yang dianggap relevan dengan rumusan masalah. Setelah mendapat data yang diinginkan, data dimasukan ke dalam kartu data untuk memudahkan peneliti dalam pengklasifikasian onomatope yang ada pada subjek serta menganalisisnya. Data yang telah dikumpulkan dijabarkan dalam bentuk paragraf untuk memperjelas hasil penelitian.

Dalam penelitian ini, data diolah menggunakan metode deskriptif kualitatif. Data yang diperoleh berupa korpus yang dianalisis adalah onomatope yang terdapat dalam mukashi banashi dan pembentukannya dalam kalimat yang ada pada sumber data dan kemudian penulis menarik sebuah kesimpulan. Tahap-tahap penelitian adalah sebagai berikut.

1. Analisis awal. Membaca dongeng yang di dalamnya terdapat data yang menunjang penelitian dilakukan.

2. Analisis lanjutan. Memasukkan data yang diperoleh ke dalam tabel data.

3. Analisis akhir. Menjabarkan onomatope yang terdapat dalam dongeng dalam bentuk paragraph dan membuat kesimpulan.

\section{Hasil dan Pembahasan}

Dalam penelitian ini ditemukan empat klasifikasi onomatope yang terdapat pada dongeng bahasa Jepang, yaitu gion'go, giseigo, gitaigo, dan giyougo. Terdapat 6 penggunaan yang tidak sesuai dengan teori, yaitu sebagai adverbia yang diikuti langsung oleh adjektiva, adverbia yang diikuti langsung oleh nomina, sebagai nomina yang tidak diikuti oleh partikel, sebagai adjektiva yang diikuti oleh verba, sebagai adjektiva yang diikuti oleh partikel ni (に), dan sebagai adjektiva yang digabungkan dengan adjektiva.

\section{Gion'go \\ Data 1}

その時穴のそこからスッテンテレツクテンテンテン楽しい小林が聞こえてきました。

Sono toki ana no soko kara suttenteretsuku tententen tanoshii ohayashi ga kikoetekimashita. Saat itu dari dalam lubang 'treng treng teng teng' terdengar suara yang menyenangkan.

Onomatope yang terdapat pada data 2 adalah suttenteretsuku tententen (スッテンテレ ツクテンテンテン) yaitu tiruan bunyi yang menunjukkan bunyi sebuah alat musik yang dimainkan. Pada kalimat dijelaskan bahwa kakek dan binatang hutan mendengar bunyi dari 
dalam lubang yang digambarkan dengan suttenteretsuku tententen (スッテンテレツクテン テンテン). Onomatope suttenteretsuku tententen (スッテンテレックテンテンテン) merupakan tiruan bunyi dari alat musik ohayashi (おはやし) yaitu sebuah alat tradisional Jepang yang biasa dimainkan ketika sedang ada perayaan atau ketika berlangsungnya festival. Onomatope suttenteretsuku tententen (スッテンテレックテンテンテン) memberikan gambaran lebih nyata ke pembaca bagaimana bunyi alat musik yang didengar oleh kakek dan binatang hutan.

\section{Data 2}

パンパンパン！「どうか子供をおさずけください」おじいさんとおばあさんは毎朝神様に手 を合わせてお祈りします。

Panpanpan! "Douka kodomo o osazuke kudasai" ojiisan to obaasan wa mai asa kamisama ni te o awasete oinorishimasu.

Pok Pok Pok! "Tolong beri kami seorang anak", kakek dan nenek setiap pagi selalu mencakupkan tangan dan berdoa kepada Dewa.

(IB: 01)

Onomatope yang terdapat pada data 5 adalah panpanpan (パンパンパン) yang memiliki arti tiruan bunyi dari tepukan tangan yang dilakukan sebanyak tiga kali. Pada kalimat dijelaskan bahwa kakek dan nenek sedang berdoa kepada Dewa agar dikaruniai anak. Masyarakat Jepang memiliki suatu tradisi yaitu menepukkan tangan sebelum memulai berdoa. Onomatope panpanpan (パンパンパン) berbeda dengan onomatope pachipachi (パ チパチ) meskipun sama-sama memiliki arti tiruan bunyi tepuk tangan. Panpanpan (パンパン パン) merupakan tepukan secara teratur yang frekuensinya sedikit dan dapat dihitung, sedangkan pachipachi (パチパチ) merupakan tepukan tangan yang dilakukan secara terusmenerus.

\section{Data 3}

バサッ! バサッ!帰る途中の雪の中でなにやら大きな物が動いているのが見えます。

BasaQ! BasaQ! Kaeru tochuu no yuki no naka de naniyara ookina mono ga ugoiteiru no ga miemasu.

Srak! Srak! Di tengah perjalanan pulang di tengah salju dia melihat sesuatu yang besar bergerak-gerak.

(TO: 03)

Onomatope yang terdapat pada data 6 adalah basaQ (バサっ) yang memiliki arti tiruan bunyi yang dihasilkan dari gerakan benda yang besar dan lebar. Pada data 6 basaQ (バサ っ) memiliki arti bunyi dari kepakan sayap burung bangau. Dijelaskan bahwa pemuda mendengar suatu bunyi dan melihat sesuatu yang besar tengah bergerak-gerak yang ternyata merupakan burung bangau. Burung bangau bergerak-gerak karena berusaha melepaskan diri dari jebakan.

\section{Data 4}

そのとき「トン!トン!こんばんは.........若い娘の声がしました。

Sono toki "Ton! Ton! Konbanwa......" Wakai musume no koe ga shimashita.

Saat itu "Tok! Tok! Selamat malam.....", terdengar suara seorang perempuan muda.

(TO: 07)

Onomatope yang terdapat pada data 8 adalah ton! ton! (トン! トン). Onomatope ini memiliki arti bunyi yang dihasilkan ketika sedang mengetuk pintu dengan pelan. Seorang perempuan sedang mengetuk pintu pemuda dengan pelan sambil mengucapkan salam. Dalam bahasa Jepang mengetuk pintu tidak hanya digambarkan dengan ton! ton! (トン! ト ン!), tetapi ada juga dondon (ドンドン). Dondon (ドンドン) memiliki arti bunyi pintu yang diketuk dengan keras. 


\section{Giseigo \\ Data 5}

りすはするするうさぎはぴょんぴょんさるはきやつきゃでためきもぽんぽこりんしかもまけ ずにぴょーんぴょんみんなでおむすびをおいかけます。

Risu wa suru suru usagi wa pyon pyon saru wa kyaQkya de tanuki mo ponpokorin shika mo makezuni pyo-n pyon minna de omusubi o oikakemasu.

Tupai, kelinci, monyet, musang, dan tidak ketinggalan rusa berlari mengejar omusubi.

(OK: 13)

Pada data 10 ditemukan lima onomatope, tetapi yang masuk ke dalam klasifikasi giseigo (擬声語) adalah onomatope kyaQkya (きやっきや). Onomatope kyaQkya (きやっきや) merupakan tiruan suara dari suara monyet. Para bintang hutan mengejar omusubi yang menggelinding. Dari binatang yang mengejar omusubi salah satunya adalah monyet. Monyet memiliki kebiasaan mengeluarkan suara ketika sedang berlari. Pada dongeng lebih terasa nyata ketika suara monyet ditulis dalam bentuk onomatope. Sehingga para pembaca membayangkan secara langsung ketika monyet sedang mengejar omusubi.

\section{Data 6}

そんなある日のこといつものようにお祈りをすませると神棚の中から「オギャーオギャー」 と赤ちゃんの泣き声が聞こえてきました。

Sonna aru hi no koto itsumo no youni oinori o sumaseru to kamidana no naka kara "ogyaaogyaa" to akachan no nakigoe ga kikoetekimashita.

Suatu hari seperti biasa, ketika mereka selesai berdoa, dari dalam kuil "oek oek" terdengar suara tangisan bayi.

Onomatope yang terdapat pada kalimat 13 adalah ogyaaogyaa (オギャーオギャー). Onomatope ini masuk ke dalam klasifikasi giseigo yang merupakan tiruan dari suara bayi ketika sedang menangis. Hal ini dapat dilihat dari akachan no nakigoe ga kikoetekimashita (赤ちゃんの泣き声が聞こえてきました) yang memiliki arti suara tangisan bayi. Meskipun penggalan kalimat tersebut sudah menunjukkan bahwa ada suara bayi yang sedang menangis, tetapi dipertegas dan ditekankan lagi dengan onomatope ogyaaogyaa (オギャー オギャー) yang menggambarkan suara tangisan tersebut. Seperti data sebelumnya, terdapat garis panjang di belakang onomatope yang menunjukkan bahwa frekuensi suara yang dihasilkan lebih panjang.

\section{Data 7}

その時ブーンとはちが飛んできてお姫様の顔をさそうとしました。

Sono toki buun to hachi ga tondekite ohimesama no kao o sasou to shimashita.

Pada saat itu ada seekor lebah 'bzzzz' yang terbang menuju wajah tuan putri dan mencoba menyengatnya.

Onomatope yang terdapat pada data 14 adalah buun (ブーン) yang memiliki arti tiruan bunyi yang dihasilkan lebah. Suara ini berasal dari sayap lebah ketika sedang terbang. Pada kalimat dijelaskan bahwa lebah sedang terbang menuju tuan putri dan mencoba untuk menyengatnya. Kepakan dari sayap lebah ini menghasilkan suara yang digambarkan dengan buun (ブーン). Pada onomatope buun (ブーン) terdapat garis panjang pada vokal yang menandakan bahwa suara yang dihasilkan berupa suara panjang. Hal ini sama seperti data sebelumnya.

\section{Data 8}

「コケコッコー!」朝です。

“Kokekokkooo!" asa desu.

"Kukuruyuk", pagi telah tiba. 
Onomatope yang terdapat pada data 16 adalah kokekokkoo (コケコッコー) yang memiliki arti suara ayam jantan. Kokekokkoo (コケコッコー) menunjukkan suara ayam dapat dilihat dari kata asa (朝) yang berarti pagi. Jika ayam berkokok menunjukkan hari sudah pagi. Begitu pula pada kalimat 16 yang menjelaskan pagi hari dan terdengar suara ayam jantan. Onomatope kokekokkoo (コケコッコー) diikuti oleh garis panjang diakhir vokal yang menunjukkan suara panjang dari onomatope tersebut.

\section{Gitaigo}

Data 9

「みんなありがとう。そろそろ朝ご飯にするとしよう。」

"Minna arigatou. Sorosoro asa gohan ni suru to shiyou"

"Terima kasih semuanya. Ayo kita segera sarapan"

(OK: 09)

Onomatope pada data 17 adalah sorosoro (そろそろ) yang masuk ke dalam klasifikasi gitaigo (擬態語). Sorosoro (そろそろ) memiliki arti keadaan ketika sedang bergegas melakukan sesuatu atau akan mengerjakan sesuatu. Pada data 17 menunjukkan bahwa kakek mengucapkan terima kasih kepada para binatang hutan yang telah membantunya. Sebagai ucapan terima kasih, kakek meminta mereka untuk segera sarapan. Untuk mempertegas makna segera pada kalimat digunakan onomatope sorosoro (そろそろ).

\section{Data 10}

ところがうっかり手がすべりおむすびはころころころりんと転がって行きました。 Tokoro ga ukkari te ga suberi omusubi wa korokoro kororin to korogatteikimashita. Akan tetapi, omusubi yang ada di tangan kakek tergelincir dan jatuh menggelinding.

(OK: 09)

Pada data 18 terdapat dua onomatope yang menunjukkan suatu kegiatan. Onomatope yang pertama adalah ukkari (うっかり) yang memiliki arti suatu keadaan yang terjadi secara tiba-tiba. Pada kalimat ukkari (うっかり) untuk menjelaskan bahwa omusubi yang ada di tangan kakek secara tiba-tiba terjatuh dan menggelinding. Onomatope yang kedua adalah korokoro kororin (ころころころりん) yang menunjukkan keadaan ketika sebuah benda bulat menggelinding. Korokoro kororin (ころころころりん) diambil dari kata korogaru (転がる) yang artinya menggelinding sehingga onomatope yang menunjukkan suatu benda bulat menggelinding adalah korokoro kororin (ころころころりん). Pada kalimat meskipun sudah terdapat kata korogatteikimashita (転がって行きました) yang menjelaskan bahwa omusubi itu menggelinding, tetapi tetap digunakan onomatope korokoro kororin (ころ ころころりん) untuk lebih menekankan keadaan omusubi tersebut.

\section{Data 11}

キラキラ輝くたんものを手にしたよさくはあまり美しさに目を見はりました。

Kirakira kagayaku tanmono o te ni shita yosaku wa Amari utsukushisa ni me o miharimashita. Pemuda itu melihat kain yang bersinar dan tampak indah di tangannya.

Onomatope yang terdapat pada data 21 adalah kirakira (キラキラ) yang memiliki arti bersinar, berkilau, atau kerlap-kerlip. Kirakira (キラキラ) merupakan onomatope yang dapat berdiri sendiri tanpa diikuti keterangan di belakangnya untuk menunjukkan arti dari onomatope tersebut. Pada data 21, onomatope kirakira (キラキラ) menggambarkan bahwa kain yang dipegang oleh pemuda tampak berkilau yang menunjukkan kain tersebut adalah kain dengan kualitas tinggi seperti kain sutra.

\section{Giyougo \\ Data 12}

おかげでみんなお腹がペこぺこになってしまいました。

Okage de minna onaka ga pekopeko ni natteshimaimashita. 
Kemudian semua menjadi lapar.

(OK: 13)

Onomatope yang terdapat pada data 24 adalah pekopeko (ペこペこ) yang merupakan suatu keadaan yang menunjukkan keadaan ketika sedang lapar. Pekopeko ( こぺこ) dapat digunakan tanpa menambahkan kata onaka ga tsuita (お腹が空いた) yang memiliki arti lapar. Onomatope ini sama dengan onomatope pada data 21 dan 23 yang dapat berdiri sendiri tanpa diikuti keterangan di belakangnya. Pada kalimat pekopeko (ペこ ヘこ) ditambahkan kata onaka (お腹) di depannya yang memiliki arti perut. Sehingga lebih menekankan bahwa semua sedang kelaparan.

\section{Data 13}

鬼のいぶくろをはりのかたなでチクチクさして大暴れしました。

Oni no ibukuro o hari no katana de chikuchiku shite ooabareshimashita.

Dia menusuk perut iblis itu menggunakan pedang dari jarum terus-menerus.

Onomatope yang terdapat pada data 26 adalah chikuchiku sashite (チクチクさして) yang menunjukkan keadaan ketika menusukkan benda tajam. Pada kalimat dikatakan bahwa Issunboushi menusuk perut iblis menggunakan jarum yang berperan sebagai pedang. Keadaan tersebut digambarkan dengan onomatope chikuchiku sashite (チクチクさ して). Onomatope chikuchiku sashite (チクチクさして) akan memiliki arti yang berbeda jika tidak diikuti oleh sashite (さして) dibelakangnya. Jika hanya chikuchiku (チクチク) onomatope ini menunjukkan suatu kondisi ketika kesakitan. Namun, memiliki arti menusuk jika ditambahkan sashite (さして) seperti pada kalimat.

\section{Data 14}

いっすんぼうしはすばやくけんをぬきピョーンと飛び上がってはちのはねをさしておいはら いました。

Issunboushi wa subayaku ken o nuki pyoon to tobi agatte hachi no hane o sashite oiharaimashita.

Issunboushi dengan cepat menarik pedangnya dan melompat 'hyaat' lalu menusuk sayap lebah tersebut.

Pada data 25 terdapat onomatope pyoon (ピョーン) yang menunjukkan suatu keadaan ketika sedang melompat tinggi. Meskipun pada kalimat telah menggunakan kata tobi agatte (飛び上がって) yang memiliki arti melompat, tetapi tetap menggunakan onomatope pyoon (ピョーン) untuk membuat keadaan tersebut terlihat lebih nyata. Sehingga pembaca dongeng khususnya anak-anak dapat membayangkan ketika Issunboushi sedang melompat untuk menusuk lebah.

Pyoon (ピョーン) memiliki vokal panjang yang menunjukkan bahwa Issunbouhsi melompat dengan tinggi untuk bisa menusuk sayap lebah. Onomatope pyoon (ピョーン) hampir sama dengan onomatope pyonpyon (ぴょんぴょん). Jika pyoon (ピョーン) terdiri dari satu kata tanpa pengulangan dan memiliki arti melompat dengan lompatan yang tinggi. Sedangkan pyonpyon (ぴょんぴょん) terdiri dari kata yang mengalami pengulangan. Onomatope ini memiliki arti melompat berkali-kali dengan jarak lompatan yang pendek.

\section{Data 15}

いっすんぼうしの小さな体がぐんぐん大きくなってあっというまにそれはすてきな若侍に変 わってしまいました。

Issunboushi no chiisana karada ga gungun ookikunatte atto iuma ni sore wa suteki wakazamurai ni kawatteshimaimashita.

Tubuh kecil Issunboushi dalam waktu singkat berubah menjadi pemuda yang tampan. Jurnal Pendidikan Bahasa Jepang | 201 
(IB: 41)

Onomatope yang terdapat pada data 27 adalah gungun (ぐんぐん) yang menunjukkan suatu keadaan ketika sesuatu mengalami perubahan ukuran dengan cepat. Pada kalimat, dijelaskan bahwa Issunboushi berubah menjadi besar dan menjadi pemuda yang tampan. Issunboushi mengalami perubahan ukuran badan dengan cepat dari kecil menjadi besar.

\section{Simpulan dan Saran}

Berdasarkan penelitian yang telah dilakukan mengenai jenis dan makna onomatope dalam dongeng bahasa Jepang, ditarik dua buah kesimpulan sebagai berikut.

1. Ditemukan 34 data onomatope pada dongeng bahasa Jepang yang ada dalam 28 kalimat. Onomatope yang ditemukan adalah 9 data gion'go, 8 data giseigo, 8 data gitaigo, dan 10 data giyougo.

2. Makna onomatope yang ditemukan dalam dongeng bahasa Jepang sangat beragam. Onomatope tidak hanya dapat diartikan secara sendiri, tetapi menyesuaikan dengan kalimat yang terdapat onomatope. Hal ini karena ada beberapa onomatope yang memiliki penulisan yang sama, tetapi memiliki arti yang berbeda atau memiliki makna yang sama dengan penulisan yang berbeda.

Saran yang dapat diberikan dari penelitian ini adalah untuk peneliti lain atau mahasiswa Program Studi Pendidikan Bahasa Jepang diharapkan dapat membuat penelitian tentang onomatope bahasa Jepang lebih dalam. Tidak hanya tentang arti dan penggunaannya, tetapi dapat dikembangkan dengan meneliti sudut yang berbeda seperti melakukan penerjemahan onomatope pada dongeng bahasa Jepang ke bahasa Indonesia atau bahasa daerah.

\section{DAFTAR RUJUKAN}

Assaneo, Mf, dkk. 2011. The Anatomy of Onomatopoeia. PLos one, Vol. 6, No. 12.

Habsari, Zakia. 2017. Dongeng Sebagai Pembentuk Karakter Anak. Jurnal Kajian Perpustakaan dan Informasi, Vol. 1, No. 1:21-29.

Hadi, Imron. 2013. A Comparison of Onomatopoeia in Foreign, Indonesian, and LocalLanguages. Madah, Vol. 4, No. 2: 185.

Hinata, Shigeo dan Hibiya Junko. 1989. Giongo - Gitaigo. Tokyo: Aratake Shuppan.

Hirata, Shogo. 1993. Yoi Koto Mama no Anime Ehon. Japan.

Kinashi, Nastiti Lintang. 2018. A Stylistic Analysis of Onomatopoeia in Walt Disney's 5 Minute Princess Stories Book. English Language \& Literature Journal, Vol. VII, No. 7: 704.

Mulya, Komara. 2013. Fukushi Bahasa Jepang. Yogyakarta: GRAHA ILMU.

Sato, Eriko. 2017. Translanguaging in Translation: Evidence from Japan Mimetics. International Journal of Linguistic and Communication, Vol. 5, No. 1: 11-26.

Sudjianto, dkk. 2012. Pengantar Linguistik Bahasa Jepang. Jakarta: Kesaint Blanc. Tjandra, Sheddy N. 2014. Sintaksis Jepang. Bina Nusantara: Jakarta.

Verhaar, J. W. M. 2008. Asas-asas Linguistik Umum. Yogyakarta: Gajah Mada University Press. 